\title{
Pola asuh pada anak gangguan spektrum autisme di sekolah autis, sekolah luar biasa dan tempat terapi anak berkebutuhan khusus di Kota Manado dan Tomohon
}

\author{
${ }^{1}$ Indah J. Larete \\ ${ }^{2}$ Liesbeth F. J. Kandou \\ ${ }^{2}$ Herdy Munayang \\ ${ }^{1}$ Kandidat Skripsi Fakultas Kedokteran Universitas Sam Ratulangi Manado \\ ${ }^{2}$ Bagian Psikiatri RSUP Prof. Dr. R. D. Kandou Manado \\ Email: indahjuliantilarete12015@yahoo.co.id
}

\begin{abstract}
Autism spectrum disorder is an extremely complex growth disorder that deals with communication, social interaction, and imagination activities that can be observed in children before they reach 3 years of age. The parenting style consists of 3 types, which are democratic parenting style, authoritarian parenting style, and permissive parenting style. This atudy aimed to identify the parenting style implemented by parents to children with autism spectrum disorders at autism schools, exceptional schools, and disabled children therapy sites in Manado and Tomohon. This was a quantitative study with a cross sectional design. There were 30 respondents who were parents of chidren with autism spectrum disorder. The results showed that of 30 respondents, 17 (56.7\%) implemented the authoritarian parenting style, 10 (33.3\%), implemented the democratic parenting style, and $3(10 \%)$ implemented the permissive parenting style. Conclusion: Most of the parents with children of autism spectrum disorder at autism school, exceptional school, and disabled children therapy sites in Manado and Tomohon implemented the authoritarian parenting style to their children.
\end{abstract}

Keywords: parenting style, children, autism spectrum disorder.

\begin{abstract}
Abstrak: Gangguan spektrum autisme adalah suatu gangguan perkembangan yang kompleks dan berat menyangkut komunikasi, interaksi social, dan aktivitas imajinasi yang dapat dilihat pada anak sebelum umur 3 tahun. Pola asuh terdiri dari 3 jenis yaitu pola asuh demokratis, pola asuh otoriter, dan pola asuh permisif. Penelitian ini bertujuan untuk mengetahui pola asuh orang tua terhadap anak yang memiliki gangguan spektrum autisme di sekolah khusus autis, sekolah luar biasa, dan tempat terapi anak berkebutuhan khusus di kota Manado dan Tomohon. Jenis penelitian ini kuantitatif dengan desain potong lintang terhadap 30 responden yaitu orang tua yang mempunyai anak gangguan spektrum autisme, dilanjutkan dengan penelitian kualitatif melalui wawancara mendalam terhadap 2 orang responden. Hasil penelitian memperlihatkan dari 30 responden didapatkan orang tua yang menerapkan pola asuh otoriter sebanyak 17 responden (56,7\%); orang tua yang menerapkan pola asuh demokratis ialah 10 responden (33,3\%); dan orangtua yang menerapkan pola asuh permisif sebanyak 3 responden (10\%). Simpulan: Sebagian besar orang tua yang memiliki anak gangguan spektrum autisme di sekolah autisme, sekolah luar biasa, dan tempat terapi di kota Manado dan Tomohon mengasuh anak dengan cara pola asuh otoriter.
\end{abstract}

Kata kunci: pola asuh, anak, gangguan spektrum autis

Gangguan spektrum autisme adalah suatu gangguan perkembangan yang kompleks dan berat menyangkut komunikasi, interaksi sosial, dan aktivitas imajinasi yang dapat dilihat pada anak sebelum umur 3 tahun. ${ }^{1}$ Anak dengan gangguan spektrum autisme adalah anak yang kondisinya menunjukkan gejala atau sindrom yang 
sangat langka dengan ciri-ciri pokok kelainannya yaitu tidak mampu berbicara atau menggunakan bahasa untuk menyampaikan maksud hatinya sendiri kepada orang lain, bertingkah laku yang sangat menyimpang dibandingkan dengan penyandang kelainan lainnya, terisolasi terhadap lingkungan karena ia senang pada dunianya sendiri serta tidak mengenal orang lain di sekitarnya melalui kontak mata, sekalipun dengan orang tuanya. ${ }^{2}$

Gangguan spektrum autisme dapat diderita oleh anak siapapun tanpa melihat status sosial dan tingkat ekonomi keluarga. ${ }^{3}$ Sampai saat ini belum ada penelitian khusus yang dapat menyajikan data gangguan spektrum autisme pada anak Indonesia. Meski belum ada angka pasti mengenai jumlah anak dengan gangguan spektrum autisme di Indonesia, namun pemerintah merilis data jumlah anak penyandang gangguan tersebut berada di kisaran 112 ribu jiwa. Jumlah kasus gangguan spektrum autisme mengalami peningkatan yang signifikan. Jika tahun 2008 rasio anak gangguan spektrum autisme 1 dari 100 anak, maka di 2012 terjadi peningkatan yang cukup memprihatinkan dengan jumlah rasio 1 dari 88 orang anak saat ini mengalami gangguan spektrum autisme. Jumlah penderita gangguan spektrum autisme di Indonesia diperkirakan mengalami penambahan sekitar 500 orang tiap tahun. Pada tahun 2013, diprediksi jumlah penyandang gangguan spekturm autisme mencapai tiga juta orang dengan perbandingan 6 dari 10 ribu kelahiran. ${ }^{4}$

Perbandingan antara anak laki-laki dan perempuan yang mengalami gangguan spektrum autisme ialah 4:1. ${ }^{5}$ Gangguan ini lebih sering ditemukan pada anak laki-laki dibandingkan pada anak perempuan, tetapi anak perempuan yang memiliki gangguan spektrum autisme cenderung terkena lebih serius dan lebih memungkinkan memiliki riwayat keluarga gangguan kognitif dibandingkan anak laki-laki. ${ }^{6}$

Pola pengasuhan menurut Baumrind terdiri dari tiga jenis yakni, pola asuh permisif, pola asuh demokratis, dan pola asuh otoriter. Pola asuh permisif, yaitu pola asuh yang menerapkan kebebasan. Dalam pola asuh ini anak berhak menentukan yang akan ia lakukan dan orang tua memberikan fasilitas sesuai kemauan anak. Pola asuh demokratis yaitu pola asuh yang menerapkan nilai-nilai demokrasi dalam keluarga. Anak dihargai haknya oleh orang tua, dan orang tua menerapkan peraturanperaturan yang dipatuhi anak selama tidak memberatkan anak. Pola asuh otoriter yaitu pola asuh yang menegaskan akan kekuasaan orangtua di dalam mendidik anakanaknya. Orangtua menerapkan peraturan tegas dengan sanksi-sanksi, dan anak wajib patuh. Dalam pola asuh ini anak sama sekali tidak diberikan kesempatan untuk memperoleh haknya. ${ }^{7}$

Pada anak dengan gangguan spektum autisme, keterlibatan orangtua serta pemberian pola asuh yang tepat merupakan hal yang sangat penting untuk memberikan pengaruh besar pada keberhasilan tumbuh kembang anak. Pembentukan perilaku anak tidak terjadi dengan sendirinya. Pembentukan perilaku tersebut senantiasa berlangsung dari interaksi yang didapatkan anak dari orangtua karena orangtua merupakan tempat interaksi yang paling dekat dan tepat. Di dalam komunikasi dan interaksi dari orangtua, orangtua perlu menerapkan pola asuh kepada anak untuk dapat membentuk perilaku anak menuju ke depannya. ${ }^{4}$

Sampai saat ini belum ada data pasti mengenai anak dengan gangguan spektrum autisme di Kota Manado dan Tomohon. Penelitian ini bertujuan untuk mendapatkan pola asuh pada anak gangguan spektrum autisme di sekolah khusus autisme, sekolah luar biasa, dan tempat terapi anak berkebutuhan khusus di Kota Manado dan Tomohon.

\section{METODE PENELITIAN}

Jenis penelitian ini ialah kuantitatif dengan pengambilan data secara potong lintang terhadap 30 orang responden mengenai pola asuh pada anak gangguan spektrum autisme dengan menggunakan kuesioner. Penelitian dilaksanakan di 
sekolah khusus autisme, sekolah luar biasa dan tempat terapi anak berkebutuhan khusus di Kota Manado dan Tomohon selama November 2015-Januari 2016. Populasi penelitian ialah semua orang tua atau pengasuh yang mempunyai anak gangguan spektrum autisme. Kriteria eksklusi dalam penelitian ini ialah orang tua atau pengasuh yang tidak bersedia menandatangani informed consent. Dalam penelitian ini variabel yang digunakan ialah pola asuh, gangguan spektrum autisme, anak, usia, tingkat pendidikan, dan jenis kelamin.

Defenisi operasional pola asuh ialah interaksi antara anak dan orang tua selama mengadakan kegiatan pengasuhan, seperti cara, kebiasaan, atau perlakuan orangtua yang diterapkan untuk menjaga, merawat, dan membimbing anak dalam rangka memenuhi kebutuhan dan memberikan perlindungan kepada anak. Gangguan spektrum autisme adalah suatu gangguan perkembangan yang kompleks dan berat menyangkut komunikasi, interaksi sosial dan aktivitas imajinnasi yang dapat dilihat pada anak sebelum umur 3 tahun. Usia diartikan dengan lamanya keberadaan seseorang sejak dilahirkan yang dinyatakan dalam satuan waktu (tahun). Anak merupakan individu yang berada dalam satu rentang perubahan perkembangan yang dimulai dari bayi hingga remaja yaitu dai 0-18 tahun. Jenis kelamin ialah perbedaan antara perempuan dengan lakilaki secara biologis sejak seseorang lahir. Tingkat Pendidikan mengacu pada jenjang pembelajaran yang telah dijalani oleh responden. Tingkat pendidikan diurutkan mulai dari: tidak sekolah, taman kanakkanak (TK), sekolah dasar (SD), sekolah menengah pertama (SMP), sekolah menengah atas (SMA) atau sekolah menengah kejuruan (SMK), dan perguruan tinggi (PT).

\section{HASIL PENELITIAN}

Total responden yang berpartisipasi dalam pengisian kuesioner mengenai pola asuh pada anak gangguan spektrum autisme ialah sebanyak 30 responden yang terdiri dari 28 responden orangtua dan 2 pengasuh, dan dilakukan pengolahan data secara deskriptif terhadap semua responden. Responden ini sudah melewati sampling frame (masuk dalam kriteria inklusi) dan sampling selection (tidak dropout dari penelitian)

\section{Distribusi pola asuh pada anak gangguan spektrum autisme}

Pada Tabel 1, dari 30 responden didapatkan pola asuh yang terbanyak dipakai oleh orangtua ialah pola asuh otoriter sebanyak 17 responden (56,7\%).

Tabel 1. Frekuensi dan persentase pola asuh orang tua pada anak gangguan spektrum autism

\begin{tabular}{ccc}
\hline Jenis pola asuh orang tua & $\begin{array}{c}\text { Jumlah } \\
\text { responden }\end{array}$ & $\%$ \\
\hline Pola asuh demokratis & 10 & 33,3 \\
Pola asuh permisif & 3 & 10 \\
Pola asuh otoriter & 17 & 56,7 \\
Jumlah & 30 & 100 \\
\hline
\end{tabular}

\section{Distribusi pola asuh pada anak gangguan spektrum autisme berdasarkan tingkat pendidikan orangtua.}

Pada Tabel 2, terdapat 1 responden pada tingkat pendidikannya SD-SMP yang menerapkan pola asuh demokratis (3,3\%). Dari 17 responden tingkat pendidikan SMA/SMK yang terbanyak ialah menerapkan pola asuh otoriter sebanyak 12 orang (40\%). Dari 12 responden tingkat pendidikan sarjana yang terbanyak ialah menerapkan pola asuh demokratis 6 orang (20\%). Jumlah responden terbanyak ialah tingkat pendidikan SMA/SMK sebanyak 17 orang (56,7\%); sebagian besar mengasuh anak dengan pola asuh otoriter yaitu 12 orang (40\%).

\section{Distribusi pola asuh pada anak dengan gangguan spektrum autisme berdasar- kan usia orang tua}

Pada Tabel 3, responden yang berumur 20-30 sebanyak 3 orang dengan pola asuh demokratis, pola asuh permisif, dan pola asuh otoriter sama banyak yaitu 1 orang (3,3\%). Responden yang berumur 31-40 
sebanyak 12 orang dengan pola asuh otoriter yang terbanyak yaitu 6 orang (20\%). Responden yang berumur 41-50 sebanyak 10 orang dengan pola asuh otoriter yang terbanyak yaitu 6 orang (20\%). Responden yang berumur 51-60 sebanyak 5 orang dengan pola asuh otoriter yang terbanyak yaitu 4 orang (13,3\%). Responden yang terbanyak pada usia 31-40 yaitu 12 orang (40\%), sebagian besar mengasuh anak dengan pola asuh otoriter yaitu 6 orang (20\%).
Distribusi pola asuh pada anak gangguan spektrum autisme berdasarkan jenis kelamin

Pada Tabel 4, anak laki-laki sebanyak 24 responden dengan pola asuh otoriter yang terbanyak yaitu 14 (46,7\%) orang. Anak perempuan sebanyak 6 responden dengan pola asuh otoriter yang terbanyak yaitu 3 (10\%) orang. Jumlah responden terbanyak ialah anak laki-laki yaitu 26 orang (80\%) dan yang diasuh dengan pola asuh otoriter yaitu 14 orang (46,7\%).

Tabel 2. Frekuensi dan persentase pola asuh pada anak gangguan spektrum autisme berdasarkan tingkat pendidikan orangtua

\begin{tabular}{ccccc}
\hline $\begin{array}{c}\text { Tingkat } \\
\text { Pendidikan }\end{array}$ & $\begin{array}{c}\text { Pola asuh } \\
\text { demokratis }\end{array}$ & $\begin{array}{c}\text { Pola asuh } \\
\text { permisif }\end{array}$ & $\begin{array}{c}\text { Pola asuh } \\
\text { otoriter }\end{array}$ & Total \\
\hline SD-SMP & 1 & 0 & 0 & 1 \\
& $3,3 \%$ & $0 \%$ & $0 \%$ & $3,3 \%$ \\
SMA/SMK & 3 & 2 & 12 & 17 \\
& $10 \%$ & $6,7 \%$ & $40 \%$ & $56,7 \%$ \\
Sarjana & 6 & 1 & 5 & 12 \\
& $20 \%$ & $3,3 \%$ & $16,7 \%$ & $40 \%$ \\
Jumlah & 10 & 3 & 17 & 30 \\
& $33,3 \%$ & $10 \%$ & $56,7 \%$ & $100 \%$ \\
\hline
\end{tabular}

Tabel 3. Frekuensi dan persentase pola asuh anak gangguan spektrum autisme berdasarkan usia orang tua

\begin{tabular}{ccccc}
\hline $\begin{array}{c}\text { Usia } \\
\text { orang tua }\end{array}$ & $\begin{array}{c}\text { Pola asuh } \\
\text { demokratis }\end{array}$ & $\begin{array}{c}\text { Pola asuh } \\
\text { permisif }\end{array}$ & $\begin{array}{c}\text { Pola asuh } \\
\text { otoriter }\end{array}$ & Total \\
\hline $20-30$ & 1 & 1 & 1 & 3 \\
& $3,3 \%$ & $3,3 \%$ & $3,3 \%$ & $10 \%$ \\
$31-40$ & 4 & 2 & 6 & 12 \\
& $13,3 \%$ & $6,7 \%$ & $20 \%$ & $40 \%$ \\
$41-50$ & 4 & 0 & 6 & 10 \\
& $13,3 \%$ & $0 \%$ & $20 \%$ & $33,3 \%$ \\
$51-60$ & 1 & 0 & 4 & 5 \\
& $3,3 \%$ & $0 \%$ & $13,3 \%$ & $16,7 \%$ \\
Jumlah & 10 & 3 & 17 & 30 \\
& $33,3 \%$ & $10 \%$ & $56,7 \%$ & $100 \%$ \\
\hline
\end{tabular}

Tabel 4. Frekuensi dan persentase pola asuh pada anak gangguan spektrum autisme berdasarkan jenis kelamin

\begin{tabular}{ccccc}
\hline $\begin{array}{c}\text { Jenis } \\
\text { kelamin }\end{array}$ & $\begin{array}{c}\text { Pola } \\
\text { asuh } \\
\text { demokratis }\end{array}$ & $\begin{array}{c}\text { Pola asuh } \\
\text { permisif }\end{array}$ & $\begin{array}{c}\text { Pola asuh } \\
\text { otoriter }\end{array}$ & Total \\
\hline Laki-Laki & 8 & 2 & 14 & 24 \\
Perempuan & $26,7 \%$ & $6,7 \%$ & $46,7 \%$ & $80 \%$ \\
& 2 & 1 & 3 & 6 \\
Jumlah & $6,7 \%$ & $3,3 \%$ & $10 \%$ & $20 \%$ \\
& 10 & 3 & 17 & 30 \\
& $33,3 \%$ & $10 \%$ & $56,7 \%$ & $100 \%$ \\
\hline
\end{tabular}




\section{BAHASAN}

Pada Tabel 1, dari 30 responden, diperoleh cara pengasuhan dengan responden terbanyak yaitu pola asuh otoriter. Hasil penelitian Tripathi ${ }^{8}$ di dua kota berbeda di India yaitu Delhi dan Dehradun mengenai pola asuh dan tingkat stres orang tua dengan anak gangguan spektrum autism. Total 320 responden yang diambil dari 10 sekolah autis di India dan didapatkan orangtua khususnya ibu dari anak-anak dengan gangguan spektrum autisme lebih menerapkan pola asuh permisif.

Jarymke et al. menyatakan bahwa orangtua dari anak gangguan spektrum autisme banyak menghadapi tantangan khususnya dalam mengasuh anak. Jarymke membandingkan pengasuhan perilaku orangtua pada anak-anak dan remaja dengan gangguan spektrum autisme tentang bagaimana perilaku orangtua dan bagaimana perilaku anak. Hasil penelitian menunjukkan bahwa ibu dengan anak gangguan spektrum autisme kurang menerapkan disiplin dan aturan pada anaknya. Hal ini menunjukkan bahwa ibu cenderung lebih banyak menggunakan gaya pengasuhan permisif ketika mengasuh anak. $^{8}$

Pada Tabel 2, dari 30 responden diperoleh responden terbanyak yaitu orangtua dengan lulusan SMA/SMK yang menerapkan pola asuh otoriter pada anak dengan gangguan spektrum autisme. Hasil penelitian dari Apriastuti $^{10}$ mengenai analisis tingkat pendidikan dan pola asuh orangtua dengan perkembangan anak yang dilakukan Desa Mudal Boyolali pada bulan Juni 2013 mendapatkan hubungan antara tingkat pendidikan orang tua dengan perkembangan anak. Pendidikan berperan yang sangat menentukan bagi perkembangan anak. Perbedaan tingkat pendidikan menyebabkan perbedaan pengetahuan. Semakin tinggi tingkat pendidikan, semakin mudah mereka menerima serta mengembangkan pengetahuan dan teknologi, sehingga akan meningkatkan produktivitas yang pada akhirnya akan meningkatkan kesejahteraan keluarga.
Orangtua yang mempunyai pendidikan tinggi akan mudah untuk menerima sumber informasi, mudah merubah perilaku, serta mudah memberi keputusan dalam memberikan didikan kepada anaknya. ${ }^{10}$

Pada Tabel 3, dari 30 responden diperoleh responden terbanyak yaitu orang tua berusia 31-40 tahun sebanyak 12 responden. Menurut Tridhonanto ${ }^{11}$ usia orangtua merupakan elemen yang memengaruhi pola asuh anak. Tujuan dari undang-undang perkawinan yang berbunyi "perkawinan hanya diizinkan jika pria sudah mencapai umur 19 tahun dan wanita sudah mencapai umur 16 tahun" merupakan salah satu upaya di dalam setiap pasangan dimungkinkan untuk siap secara fisik maupun psikososial untuk membentuk rumah tangga dan menjadi orangtua. Walaupun demikian rentang usia tertentu baik untuk menjalankan peran pengasuhan. Bila terlalu muda atau terlalu tua, maka tidak akan dapat menjalankan peran-peran tersebut secara optimal karena diperlukan kekuatan fisik dan psikososial.

Pada Tabel 4, terdapat 30 responden yang terbanyak mempunyai anak dengan gangguan spektrum autisme berjenis kelamin laki-laki yaitu sebanyak 24 responden, dan dari 24 reponden terdapat 14 responden menerapkan pola asuh otoriter. Menurut Kaplan et al. ${ }^{5}$ gangguan spektrum autisme ditemukan lebih sering pada anak laki-laki dibandingkan pada anak perempuan. Tiga sampai lima kali lebih banyak anak laki-laki yang memiliki gangguan spektrum autisme dubandingkan anak perempuan tetapi anak perempuan yang memilki gangguan autisme cenderung terkena lebih serius dan lebih mungkin memiliki riwayat keluarga gangguan kognitif dibandingkan anak laki-laki.

\section{SIMPULAN}

Orangtua yang memiliki anak dengan gangguan spektrum autisme kebanyakan mengasuh anak dengan pola asuh otoriter, diikuti pola asuh demokratis, dan hanya sedikit yang mengasuh anak mereka dengan pola asuh permisif. 
DAFTAR PUSTAKA

1. Rachmayanti S, Zulkaida A. Penerimaan diri orang tua terhadap anak autisme dan perannya dalam terapi autisme. Psikologi. 2007;1:8.

2. Setyawan F. Pola penanganan anak autis di Yayasan Sayap Ibu [Skripsi]. Yogyakarta: Fakultas Dakwah Universitas Islam Negeri Sunan Kalijaga; 2010.

3. Aritonang E, Pardede A, Evirka E. Pengetahuan, sikap dan tindakan ibu dalam pola makan anak penderita autis di Yayasan Tali Kasih. Kedokteran Indonesia. 2009;1:102.

4. Silaban E. Pengaruh pola asuh orang tua terhadap perilaku anak autis di Yayasan Tali Kasih Medan [Skripsi]. Medan: Universitas Sumatera Utara; 2014.

5. Kaplan H, Sadock B, Grebb J. Gangguan Perkembangan Pervasif. In: I Made Wiguna S, penerjemah. Sinopsis Psikiatri Jilid Dua. Tangerang: Binarupa Aksara Publisher, 2010.

6. Anggono T. Autisme. Yogyakarta: Pusat
Terapi dan Pendidikan Anak Autis, 2012; p. 1.

7. Efendhi F. Pengaruh pola asuh orang tua terhadap kemandirian dalam belajar siswa. Ilmiah Pendidikan Bimbingan dan Konseling, 2014.

8. Tripathi N. Parenting style and parents' level of stress having children with autistic spectrum disorder (CWASD). Journal of Neuropsychiatry. 2015;1:3-4.

9. Boonen H, van Esch L, Lambrechts G, et al. Parenting behaviors in families of school-aged children with autism spectrum disorder: An observational and questionnaire study. J Autism Development Disorder. 2015;45: 3580-93.

10. Apriastuti DA. Analisis tingkat pendidikan dan pola asuh orang tua dengan perkembangan anak. Jurnal Ilmiah Kebidanan.2013;4;8-12.

11. Tridhonanto AL, Beranda Agency. Mengembangkan Pola Asuh Demokratis (1st ed). Jakarta: PT. Elex Media Komputindo, 2014. 